Citation: A. Ottaviani (2021) The Opposite Poles of a Debate - Lapides figurati and the Accademia dei Lincei. Substantia 5(1) Suppl.: 19-28. doi: 10.36253/Substantia-1275

Copyright: @ 2021 A. Ottaviani. This is an open access, peer-reviewed article published by Firenze University Press (http://www.fupress.com/substantia) and distributed under the terms of the Creative Commons Attribution License, which permits unrestricted use, distribution, and reproduction in any medium, provided the original author and source are credited.

Data Availability Statement: All relevant data are within the paper and its Supporting Information files.

Competing Interests: The Author(s) declare(s) no conflict of interest.

\section{The Opposite Poles of a Debate - Lapides figurati and the Accademia dei Lincei ${ }^{1}$}

\author{
Alessandro Ottaviani \\ Università di Cagliari, Dipartimento di Pedagogia, Psicologia, Filosofia, via Is Mirrionis \\ 1, 09123 Cagliari \\ E-mail: alessandro.ottaviani@unica.it
}

\begin{abstract}
The essay analyses the research carried out by some members of the Accademia dei Lincei on lapides figurati, namely by Fabio Colonna on animal fossils, and by Federico Cesi and Francesco Stelluti on plant fossils; the aim is to show the role played by the Accademia dei Lincei in establishing during the second half of the seventeenth century the opposite poles of the debate on the lapides figurati, on the one hand as chronological indices of a past world and, on the other, as sudden outcome of the vis vegetativa.
\end{abstract}

Keywords: Accademia dei Lincei, Fabio Colonna, Federico Cesi, Francesco Stelluti, Fossils, lapides figurati, Rationes seminales.

\section{FABIO COLONNA ON FOSSILS}

The research of Fabio Colonna (1567-1640) is fairly well known among historians of science, particularly in the fields of geology and palaeontology. ${ }^{2}$ Given the links with Niels Steensen (1638-1686) and Agostino Scilla (1629-1700), these researches have concentrated on the 1616 dissertation on glossopetrae, ${ }^{3}$ at the expense of several interesting observations already ventilated in 1606. The latter deserve analysis because Colonna there sets out the convictions at which he had already arrived on the basis of his initial inquiries, and which were to nourish the more accurate analyses contained ten years later in the dissertation. This early stage is represented in the long

\footnotetext{
${ }^{1}$ English translation by Peter Mason.

${ }^{2}$ On Colonna and 'palaeontological' themes cf. N. Morello, "Fabio Colonna e gli inizi della paleontologia”, Physis, 1977, 19: 247-278; Ead., La nascita della paleontologia nel seicento: Colonna, Stenone e Scilla, Milano, Franco Angeli, 1979; A. Ottaviani, O. Trabucco, Theatrum naturae. La ricerca naturalistica tra erudizione e nuova scienza nell'Italia del primo Seicento, Napoli, La Città del Sole, 2007; A. Ottaviani, "Methodus philologica e naturales quaestiones fra l'Accademia dei Lincei e Galileo Galilei” Galilaeana. Studies in Renaissance and Early Modern Science, 2017, 14, 2017: 39-59; Id., "Fra diluvio noaico e fuochi sotterranei. Note sulla fortuna sei-settecentesca di Fabio Colonna" Giornale critico della filosofia italiana, 2017, 96: 272-303.

${ }^{3}$ Cf F. Colonna, De glossopetris dissertatio, in Id., Purpura. Hoc est de purpura ab animali testaceo fusa, e hoc ipso animali, aliisque rarioribus testaceis quibusdam..., Romae, Apud Jacobum Mascardum, 1616, pp. 31-39.
} 
twenty-first chapter of the Observationes, included as an appendix in the Ekphrasis published in Rome by Guglielmo Facciotti. The opening of the chapter may confuse the reader: after a series of observations on cartilaginous fish, gastropods, marine invertebrates, mammals, reptiles and insects, Colonna unexpectedly introduces the bare outline of a theory on the origin of stones. Without preamble, in a style reminiscent of the De lapidibus of Theophrastus, Colonna concisely indicates the material causes (water and earth) and efficient causes (heat and cold), ${ }^{4}$ and the effect of their various combinations. However, he continues, there are denser and purer concretions materially caused by those vapours that are drawn upwards by heat before freezing immediately in the atmosphere. ${ }^{5}$ Colonna compares the process to an experience familiar to all: the concretions of the solfatara of Pozzuoli, which are obtained in a similar way in chemical laboratories, ${ }^{6}$ or the stony incrustations produced by fumes. They seem to support the hypothesis that stones have a generic vegetal nature, and that their increase in size should be understood as a genuine process of growth. ${ }^{7}$ Yet that would be a hasty conclusion,

${ }^{4}$ F. Colonna, De Aquatilibus aliisque animalibus quibusdam libellus in ID., Minus cognitarum Stirpium ac etiam rariorum nostro coelo orien-

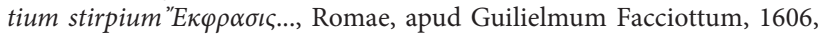
p. XLIII: «Adeo duo haec elementa cohaerent, terra scilicet et aqua, ut ex eorum quotidiana ad invicem commixtione maxime lapides generari perpetuo pro certo compertum habeamus. Nec alia est lapidis concretio, nisi terrae pars tenuior et purior aquae commixta, vel impurior aut terrestrior aqua, a solis calore exucta humiditatis parte ac etiam ab ambiente terra coire incipiens, frigore densata reliqua, sicciore deinde utrisque concurrentibus longo tempore intercedente in totum soliditatis naturam adepta, cum antea terreus liquor, vel aqueus lentus ac glutinosus esset. Terra quidem solis calore concocta aquis madefacta lentescit, nec minus quam arte effecta calx vel gypsum aqua mixtum liquescit ac facile coit, et exucta aquae parte, ab illa ignea natura per coctionem acquisita, reliqua ab extranea solis et frigoris vi exiccata, lapidis naturam adipiscitur. Densior vero, durior, aut fragilior lapis erit, si purior vel impurior, tenuior vel crassior terra immutata erit, magis vel minus solis ardoribus excocta, et deinde maioribus, vel minoribus frigoribus densata, longiore tempore perfecta».

${ }^{5}$ Ivi, p. XLIV: «Est et alia densior puriorque lapidum concretio, quae non ab ipsa terra vel aqua ad invicem imbribus commixtis efficitur ut superior, sed $\mathrm{ab}$ eorum vaporibus sursum elatis atque densatis, ut sunt lapides e caelo cum fulgure decidentes, durissimi atque politi».

${ }^{6} \mathrm{Ibidem}$ : Verum, ut exemplum afferamus quod oculis subiici et ex eo coniici possit modus elevationis vaporis et congelationis, proponemus sulphureas evaporationes Puteolanas,quae nobis aqueae videntur, attamen circa saxa specus e quo exeunt, sulphur adhaeret salis modo concretum, sed et ipsum artificiale sulphur: ex terra lapidibus calore vaporantibus, veluti per alembicum ex fornace fluit humor, qui sulphur est, sic et alia mineralia».

${ }^{7}$ Ibidem: «Sed et fuligo in caminis nonne, praeter illam spongiosam aut lanosam, in superficie alia subest crustosa dura? Et nihil aliud est nisi lignorum humiditas, tamen terream adeo magnam secum habet naturam, ac etiam lentorem quendam, ut in ligneis caminis observatur veluti pice infectis splendida vitrea crusta intectis fumo illam efferente. Ex huiuscemodi vero concretione facta lapides quidem vegetabilem quandam naturam habere conspiciuntur atque crescere illos quis putare posset».
Colonna goes on to explain, because the increase in size of a stone can come about by the mere successive accumulation of parts according to two different modalities: augmentation from an external source or from the matrix of the stone. ${ }^{8}$ The former resembles the way that shells grow through the hardening of the secretion that the animal periodically deposits on the edge of the shell; the latter is like the way in which nails and teeth grow from their matrix. ${ }^{9}$

There is no need here to follow the successive observations. In each case the focus is confined to the data observed, rendering virtually impossible any hypothesis on Colonna's sources. We know, however, that he owed his training to frequent direct contact with the recognised expert apothecary Ferrante Imperato (15501631). In 1599 Imperato had published the results of his researches, a large part of which was dedicated to the study of soils, metals, stones and gems. He offered several modalities for their genesis, some of them corresponding to those indicated by Colonna. ${ }^{10}$ Master and pupil were not in complete agreement, however: Ferrante Imperato discussed not only the successive augmentation but also the truly vegetal property of stones, ${ }^{11}$ a thesis from which, as we have seen, Colonna

${ }^{8}$ Ibidem: «Verum augmentum lapidi venit additione superveniente, ambiente vel, ut in his, ab imo succurrente, quare, veluti ab radice, alimentum et augmentum habere videtur».

${ }^{9}$ Ibidem: «Exemplum in dentibus et unguibus. De his quae per additionem crescunt, ut in testaceis maritimis et terrestris cochleis, quibus non centrum, sed circumferentia ampliatur. Signa rugarum testantur hoc ipsaque extremitas orae veluti cartilaginea, duritiem adhuc non habens, ex ambiente humore viscido ipsius animalis generata».

${ }^{10}$ F. Imperato, Dell'Historia naturale..., Napoli, per Costantino Vitale, 1599, p. 587: «Vien dunque in considerazione se le gemme da principio si apprendano nella propria grandezza come gli parpuglioni si concreano dentro delle lor cruste chiamate da alcuni aurelia, o se pigliano aumento da piccolo principio, come le creature crescono nel ventre materno e le foglie e i frutti nelle piante, o se crescono per semplice aggiunte fatte dalle radici come il capello e l'ungia, percioche si vede ciascuna delle dette manier haver propri argomenti [...]»; on Imperato cf. B. Accordi, "Ferrante Imperato (Napoli 1550-1625) e il suo contributo alla storia della geologia", Geologica Romana 1981, 20: 43-56; E. Stendardo, Ferrante Imperato. Collezionismo e studio della natura a Napoli tra Cinque e Seicento, Napoli, Accademia Pontaniana, 2001.

${ }^{11}$ Ivi, pp. 460-61, 659, 689: «E se noi consideriamo il modo del movimento et il corso delle fibre che dalle radici della marchesite si distendono, vederemo manifestamente in esse la virtù vegetale non dissimile a gli altri vegetali [...]. Dall'historia del Lyncurio più che da alcuna altra delle pietre narrate possiamo argomentare la virtù vegetale nella natura delle pietre qual molti hanno negato come cosa da quelle aliena; ma che la vegetazione che propriamente intendiamo essere laccrescimento da principio interno non sia da questo geno aliena, possiamo riconoscere nelle parti dell'istessi animali percioche le corteccie degli animali marini che sono nel geno ostracino e non meno delle chiocciole terrene sono manifestamente di consistenza di pietra e si cuociono in calce non altrimenti che le pietre [...]. E si ha della sua vegetazione [del marmo] argomento molto evidente, percioche si sono ritrovate le cave già prima fatte nel successo di tempo rinchiuse dall'accrescimento della pietra». 
was to distance himself. This is the move that provides the implicit but decisive characterisation of the lithological framework that he uses to introduce the real subject of the chapter: the description of the substantial series of fossils found. This commences with an interesting note on changes in the process of lithification depending on environmental conditions. In this context Colonna isolates two fundamental poles, that typical of arid, torrid zones, and that to be found in the cold, snowy and humid conditions of mountainous areas. ${ }^{12}$ Colonna concentrates on the former, adducing a series of observations conducted in the environs of the small town of Andria in Apulia. Inspection of this hilly terrain with its tuff slopes revealed, surprisingly, a large number of shells stuck together in a perfect state of preservation that permeated the entire area. ${ }^{13}$ As for the mountainous habitat, Colonna made observations during his frequent journeys over the Apennines, leading him to conclude that the fossils resulting from the process of putrefaction induced by humidity were of a very different kind, in which the lithic component had replaced the initial structure. Colonna was aware that it was cases like this that had led to the thesis of chance formation (lusus naturae), but the analysis of the structure, inserted within a temporal framework that Colonna vaguely defines as immemorial, suggests that they are the result of a slow decomposition of the organic remains and their successive lithification in parallel with the gradual transformation of the soil into a lithic state. ${ }^{14}$ Colonna found confirmation of this

\footnotetext{
${ }^{12}$ Colonna, De aquatilibus aliisque animalibus quibusdam libellus, $\mathrm{p}$. XLV: «In montibus nivosis quidem ob continuam humoris abundantiam aquarum et nivium terra magis excolatur et colligitur in alveis in quibus deinde densatur atque ob humoris frequentiam ligna, cornua, animalium ungues, dentes, ossa, testacea crustacea e similia putrefiunt, quamquam a frigore servari possent, quod minime evenit in locis calidioribus et maritimis ut observavimus. Nam ibi ob humoris paucitatem et nimiam siccitatem potius servantur veluti condita ab aëre et humore tuta, quae ibi obruta inveniuntur».

${ }^{13}$ Ivi, pp. XLV-XLVI: «Et ut experientia comprobari hoc videatur, nostram in hoc observationem afferemus, quam omnes veram fateri oportebit. Apuliae tractus in quo civitas nobilis est Andria dicta, tota collibus et clivis referta tophaceis, quibus ad aedificiorum ornamenta et structuras arte elaboratis utuntur, et per totam fere Apuliam etiam similibus. Quibus conspectis, nihil aliud quispiam esse dixerit, quam acervum sive potius massam testaceorum maritimorum terreno glutine confectam, atque varia cochlearum conchyliorum testaceorumque fragmenta ac etiam integra observabis nullam corruptionem adhuc temporis passa. Nec in quolibet communi manuali lapide duo aut tria conspicies, sed totum ex illo confectum dices, ut vix altera fit terrae portio. Nec etiam uni lapidi hoc accidere, sed toto colli, nec uni sed omnibus per totam illam regionem».

${ }^{14}$ Ivi, p. XLVI: «Non autem hoc ita in Apenninis montibus evenit, ut diximus, rebus humorem adversantibus et in terram putrescentibus. Nam et ipsas maritimorum animalium testas putrescere ibi certum est, sicut ligna, ossa et terrestres etiam cocleas et alia de quibus dicemus. Quae omnia non integra et veluti servata, sed penitus putrefacta in lapi-
}

in the exact correspondence of the delineatio of those forms transformed into stone to living creatures (see Figs. 1 and 2). Since that correspondence was not generic but specific, it could not be the result of a fortuitous generation. ${ }^{15}$

Colonna continues with a series of descriptions of fossils, accurately drawing from them those analyses of comparative morphology required to distinguish clearly between figured stones and fossils. Although he applied this morphological criterion with great precision - in this respect he was perhaps unequalled in his own day and only later by Steensen and Martin Lister - it had a weakness that he rapidly recognised. While Ferrante Imperato admitted the vegetal property, this was not incompatible with an explanation of fossil formation in terms of successive lithification. His son Francesco Imperato (1570 ca.- post 1629) adopted a solution that was equally possible and more linear: in an opusculum published in 1610, he did not rule out the possibility that the fossils found in the mountains might have been transported there by the flood, but this could only be applicable to those scattered on the surface; for those buried more deeply it was necessary to appeal to the action of a vegetal faculty. He emphasised the potency of this faculty, whose mimetic property rendered morphological similarities far less conclusive: 'So it is necessary to admit that it originates within the earth and then that it originates not fortuitously, but by an intrinsic vegetal capacity, while retaining the aspect of its counterparts.'. ${ }^{16}$ The vegetabilis facultas also applied to the glossopetrae, contrary to those who ascribed their origin to the teeth of sharks. Imperato considered that explanation impossible because of the quantity of glossopetrae found, which

dem versa vel potium saxum, ut ad siliceam naturam parum accedere videantur ob duritiem, densitatem et levorem, cum illa in Apulia servari videantur a tophacea concretione fragili admodum respecta saxorum. Huius rei contemplationis causa fuerunt varia testacea aliaque naturalia intra saxorum moles inventa eadem saxorum natura, sed propria effigie servata. In quorum structura animadvertendum censuimus, illa non sic intra saxa naturam efformasse fortuito, ut aliqui putant, sed immemorabili tempore ab hominibus deiectis et casu terra obrutis, intra humum putrescentibus, illa sicut ambiens terra in lapidem deinde mutata elementorum perpetua vicissitudine, non minus ac excussores ac sculptores faciunt ex convexa cavam effigiem atque e contra convexam».

${ }^{15}$ Ibidem: "Hoc testari videtur exacta admodum illorum delineatio atque cum ipsis naturalibus similitudo atque etiam copiosa eiusdem rei, eiusdem effigiei magnitudinis et structurae inventio. Non enim, si casu an natura effingerentur, tam similes et exacte formarentur ut eadem prorsus res, non dicimus species, videatur».

${ }^{16}$ Cf. Fr. Imperato, De fossilibus opusculum..., Neapoli, Typis Jo. Dominici Roncalioli, 1610, p. 69: «Unde opus est fateri intra terram ortum ducere et successive, non casualiter, sed vegetabili facultate iniuncta originem ducere similium servata effigie»; on this opusculum see Fr. Imperato, De fossilibus opusculum (1610), (Eds.: F. Brattolo, F. Coletta, M. Pladini, C. Pisaniello, C. Porcaro, E. Stendardo), Napoli, Accademia Pontaniana, 2015. 

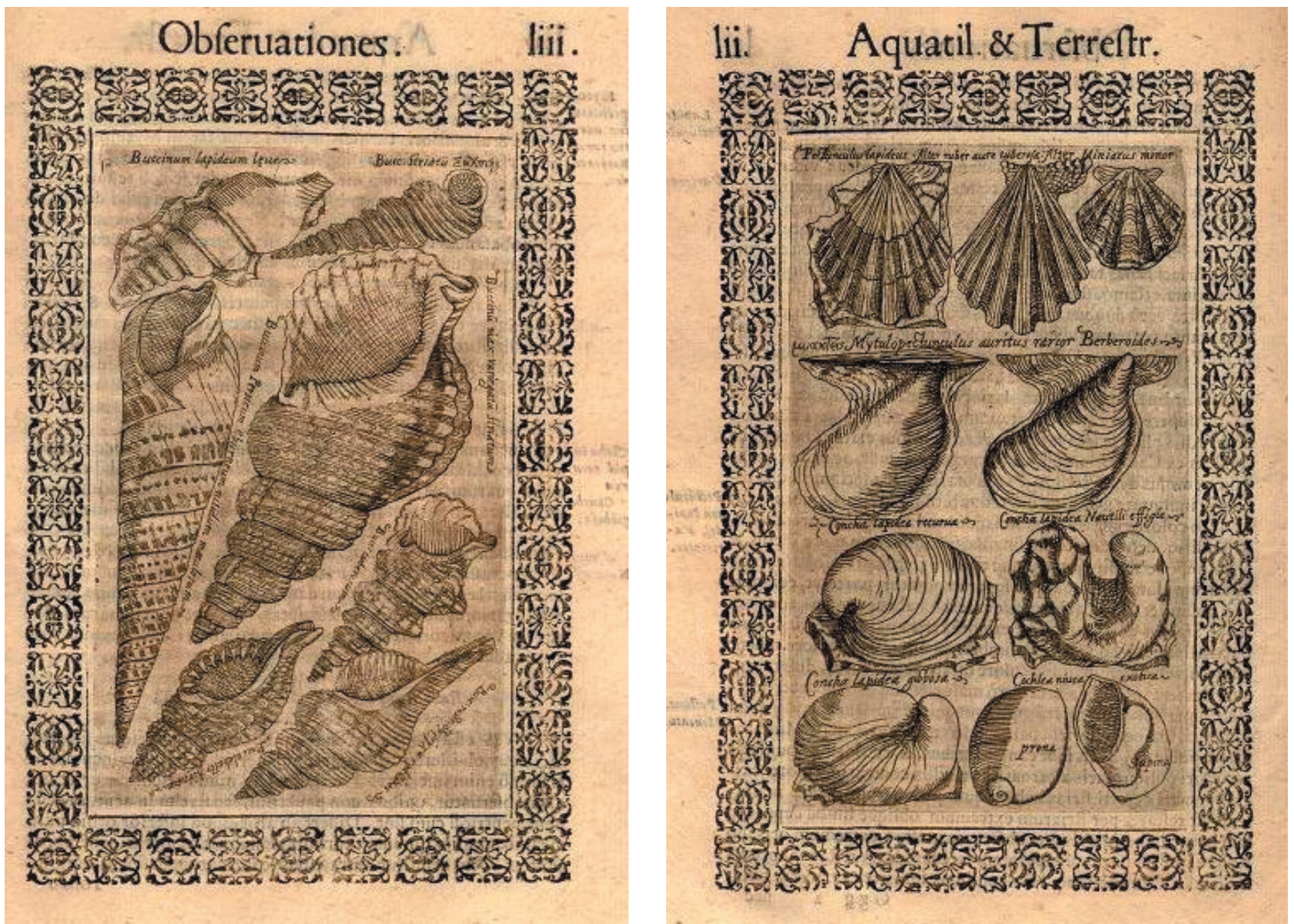

Figures 1 \& 2. Two plates from Colonna, De Aquatilibus aliisque animalibus quibusdam libellus (1606), representing shells of fossil and living animals. The fossil specimens are: Fig. 1. Pectunculus lapideus (upper left corner); Concha lapidea recurva and Concha lapidea Nautili effigie (both on the second line from the bottom); Concha lapidea gibbosa (lower left corner); Fig. 2. Buccinum lapideum laeve (upper left corner). Colonna claims to have found them in the environs of Andria, in Puglia, and in the fortress of Campochiaro, in Molise. The other represented specimens are all from living animals.

he regarded as incompatible with the number of sharks to have populated the seas since the beginning of the world (though he does not reveal the basis of his calculations): 'Indeed, on the island of Malta we discover every day tooth-shaped stones, which are (mistakenly) taken to be the teeth of sharks; because they are extracted in such numbers all over the island that they exceed the number of teeth of all the cetaceans that ever lived from the origin of the world down to the present day'. ${ }^{17}$

Colonna's response to this implicit polemic was to concentrate on the glossopetrae, conducting not only the usual morphological comparisons but also subject-

\footnotetext{
${ }^{17}$ Ivi, pp. 69-70: «Equidem in Melita Insula quotidie cernimus lapides quosdam dentium formas exprimentes, qui lamiarum dentes putantur (sed falso); nam ex qualibet dictae Insulae parte adeo copiose eliciuntur, ut nec omnium cetorum dentes, qui ab origine mundi usque num vitam duxere, illorum numerum aequare possint».
}

ing them to chemical analysis. He regarded the different products obtained from combustion of the fossil part and the lithic part as proof that the matrix and the tooth had different origins. It was an ingenious but inconclusive attempt, since the glossopetrae were derived from a 'warm' environment. The results obtained from lithic fossils extracted from mountainous and snow-covered terrains might be very different - an objection that was often raised in the subsequent debate. ${ }^{18}$

${ }^{18}$ At least down to the beginning of the following century, for which cf. E. Camerarius, Dissertationes Taurinenses epistolicae physico-medicae..., Tubingae, Impensis Joh. Georgii Cottae, 1712, pp. 268-279, which reports on the chemical analyses by Guillaume Rivière: cf. J. Gaudant. "Une nouvelle contestation de la nature organique des fossiles: les Dissertationes taurinenses Epistolicae physico-medicae d'Elias Camerarius (1712) Travaux du Comité français d'Histoire de la Géologie, s. III, 2012, 26: $235-240$. 


\section{CESI AND STELLUTI ON METALLOPHYTES}

In the years intervening between 1606 and 1616 Fabio Colonna was admitted to the Accademia dei Lincei. The De glossopetris dissertatio was an independent work, but became attached to the malacological treatise De purpura. The two works were then combined with the botanical work entitled Minus cognitarum stirpium Pars altera published in Rome by Giacomo Mascardi, ${ }^{19}$ underlining the ascription to the Lincei. It was during the preparation of the Thesaurus Mexicanus that the Neapolitan, who was by now involved with the Roman associates, first came into contact with Prince Federico Cesi's researches on lapides figurati. The occasion was the dispatch of a proof of the first pages of the Tabulae phytosophicae that Federico Cesi (1585-1630) planned to include among the commentaries contained in the volume. In a letter of 10 November 1628 to Francesco Stelluti (1577-1653), who was acting as intermediary, Colonna gave his first impression from Naples after a hasty perusal of the tables: 'The first sheet, the table of the whole Thesaurus and the principle of division or rather distinction, gave me great pleasure. I am certain that the ingenuity of Your Excellency is such that I hope it will command universal admiration when parts of these things appear in print'. ${ }^{20}$ Though time was pressing, Colonna commented on some links in Cesi's remarkable chain and formulated some possible diagnoses of them. One of these concerned the zoolithophyton, the other the Pianta Metallo, which he thought might be identified with Ferrante Imperato's marcasite (argento ramoso). ${ }^{21}$

In the latter case Colonna was wide of the mark, but in a certain sense he was correct in assuming that the answer should be sought among the treasures of the apothecary. After all, Cesi had visited Imperato in 1604 in the course of his trip to Naples and had observed there, as Francesco Stelluti recalled in 1630, a cytisus (a genus of plant) and some pieces of fossil ebony. ${ }^{22} \mathrm{Co}-$

${ }^{19}$ Cf. F. Colonna, Minus cognitarum stirpium par altera..., Romae, Apud Iacobum Mascardum, 1616.

${ }^{20}$ G. Gabrieli, Il Carteggio Linceo, Roma, Accademia Nazionale dei Lincei, 1996, p. 1187.

${ }^{21}$ Ivi, pp. 1187-88: «Io non so per dire il vero che cosa sia la pianta animale lapidea, sotto il nome di zoolithophyton, che desidero sapere come cosa da me finhora non osservata, credo per non l'haver havuto: così anco la Pianta Metallo, se pur sia differente dall'argento ramoso descritto dall'Imperato"; for the reference to marcasite see above, note 10 .

${ }^{22}$ Cesi describes the journey in a letter to Stelluti dated 17 July 1604 in ivi, pp. 40-41; cf. also F. Stelluti, Persio tradotto in verso sciolto e dichiarato, Roma, appresso Giacomo Mascardo, 1630, pp. 169-170: «Mi ricordo bene che in Napoli il Signor Ferrante Imperato Autore di un Museo così ricco e celebre, mostrò al nostro Signor Principe Cesi $[\ldots]$ una spezie di Citiso, come parve ad esso Signore, quale si potrà vedere, e qualche de gli Ebani minerali dice da esso scoperti, ne suoi libri de Metallofiti, che presto doveranno stamparsi»; Stelluti was anticipated by Faber lonna was not in Naples on that occasion, but we may suppose that, even when he was, he would not have retrospectively recalled that mineralised ebony, which Ferrante Imperato explained simply as the remains of fossil wood. ${ }^{23}$ The extant documentation shows that Cesi must have discovered his Pianta Metallo in the first decade, ${ }^{24}$ but there is little information about that until the beginning of the second decade, when Cesi had already decided to make his contribution to the Thesaurus in the form of tables and to confer a strategic role on the socalled intermediate natures in order to illustrate effectively the continuum of the divine creation. He wrote to Johann Faber (1574-1629) asking for information regarding 'whether anyone has distinguished and listed fossils in an orderly fashion in their classes, particularly the metallic ones and semi-minerals; and likewise whether anyone has summarised the sciences synoptically in tree structures and tables. ${ }^{25}$

We do not have Faber's reply, nor can we reconstruct the reading and researches leading to 1624 , the year in which Johann Baptist Winther (? - 1628 ca.), writing to Faber on 18 May, mentions a double excursion with Cesi in the course of which he drew the prince's attention to a 'certain point' in the De metallicis libri tres by Andrea Cesalpino (1519-1603); Cesi declared that it coincided with his own opinion. ${ }^{26}$ The passage in question is part of the forty-first chapter of the second book in the section on gemmae pellucidae. It is introduced by a premise intended to make it clear that the chapter will deal only with fossil ebony and not black coral. Cesalpino knows that many authorities take them to be related, if not identical, but the only thing in common that he is prepared to concede is their colour. Otherwise

in his commentary in the Thesaurus Mexicanus, already printed in 1628, in which he reported Cesi's discovery without going into the merit of the thesis regarding its origin: see Rerum medicarum novae Hispaniae thesaurus seu plantarum, animalium, mineralium Mexicanorum historia..., Romae, Ex Typographeio Vitalis Mascardi, 1651, pp. 502-503.

${ }^{23}$ F. Imperato, Dell'Historia naturale, op. cit. pp. 668-669; the same opinion in Fr. Imperato, Discorsi intorno a diverse cose naturali, Napoli, Nella Stamperia di Eg. Longo, 1628, pp. 3-4.

${ }^{24}$ A.C. Scott, "Federico Cesi and his field studies on the origin of fossils between 1610 and 1630", Endeavour, 2001, 25(3): 93-103; also useful G. Godard, "Les travaux géologiques de la première Accademia dei Lincei (1603-1651)", Travaux de comité français d'histoire de la géologie, 2011, s. III, 75(5): 119-137.

${ }^{25}$ Gabrieli, Il carteggio linceo, p. 732.

${ }^{26} \mathrm{Ivi}$, p. 881: «Siano stati due volte in luogo montuoso et argilloso, dove si trovano certi sodissimi legni in gran quantità, negre et odorate, con bellissime vene sotto terra, stimati dal Sig.r Principe Minerali, sonno bene grandi argomenti del sito e della sostanza d'alcuni di loro petrificata. Io, havendo letto nel Cesalpino il capo del Ebano, ho trovato un certo punto, il quale mostrato al Sig.r Principe gli confermò totalmente la sua opinione, se bene non mancano argomenti in contrarium validissimi, tanto ch'io non so che dirmi sin'hora. Però mi mostro d'andare con i piedi ne la opinione del Sig.r Principe». 
they originate in different environments - black and all other corals in the sea, fossil ebony on land - and their nature remains to be determined. If black coral is undeniably vegetal, the nature of fossil ebony is inscrutable; Cesalpino does not exclude the possibility that it is a root or wood that has been lithified, like coral, or that it is a stone that simply resembles wood. ${ }^{27}$ The ambiguity went back to the ancient sources such as Pausanias, whom Cesalpino quotes. He reports the explanation of a Cypriot that ebony was a sort of subterranean vegetal lacking leaves and fruit: 'Ebony does not grow leaves or bear fruit, or even appear in the sunlight at all, but consists of underground roots which are dug up by the Ethiopians, who have men skilled at finding ebony'. ${ }^{28}$ More recent discoveries, such as those made in the environs of the town of Hildesheim in Lower Saxony, reported at length by Giorgio Agricola (1494-1555) in his De natura fossilium libri $X$, failed to resolve the question either, ${ }^{29}$

${ }^{27}$ A. Cesalpino, De metallicis libri tres..., Romae, Ex Typographia Aloysii Zannetti, 1596, Liber II, cap. XLI, pp. 126-127: «Ad gemmas non pellucidas reduci possunt corallii, rubrum, candidum, et nigrum, quod Antipathes dicitur. Egimus autem de iis inter plantas. Antipathi similis est Ebenus fossilis, sive radix sit, lignumve Ebeni in lapidem concreti, sive omnino lapis per se genitus ligno similis. Differt a Corallio nigro: hoc enim non nisi in mari nascitur; ebenus foditur»; Gabrieli, Il carteggio linceo, cit., p. 112, n. 3 assumes Winther was referring to A. Cesalpino, De plantis libri XVI, Florentiae, Apud Georgium Marescottum, 1583, Lib. 3, cap. XXXIIII, pp. 114-115, that contains, at any rate, the same opinion on the Ebenus fossilis.

${ }^{28}$ Pausanias, Description of Greece with an English Translation by W.H.S. Jones, London, William Heinemann-New York, G.P. Putnam's Sons, 1918, pp. 227, 229; followed by a reference to Theophrastus: see Cesalpino, De metallicis libri tres, p. 127: «Et Theophrastus tradit Ebenum fossilem inveniri inclusum aliis lapidibus tamquam foetum in ventre. $\mathrm{Si}$ igitur haec vera sunt, nec radix nec arbor dicenda est in lapidem conversa, sed lapis Ebeno similis in fibris Saxorum genitus». The passage, however, does not correspond to any of those in which Theophrastus discusses ebony.

${ }^{29}$ Cesalpino, De metallicis libri tres, p. 127: «Nec tamen absurdum etiam Ebeni lignum intra terram diu conditum lapidescere, quod \& aliis generibus lignorum contigisse compertum est», followed by a reference to G. Agricola, De natura fossilium libri X, Basileae, In Officina Frobeniana, 1558, pp. 324-325: «In Hildesheimio quoque in terra aluminosa inventum est lignum quernum in lapidem conversum. In eodem e regione arcis Marieburgi collis est plenus lapideis trabibus, quarum capita interdum eminent. Sunt vero perlongae, acervatim positae, inque medio earum terra est, colore nigra, ferro aut altero lapido percussae non aliter nec marmor Hildesheimium, de quo supra dixi, cornu usti virus olent, omninoque ex eadem materia sunt, quare cum natura lapides arborum similes procreet, diligenter videndum est an corticem et medullam aliaque habeant. Quae si absunt non stipites in lapides conversi sunt, sed natura fecit lapides stirpium simillimos, quales sunt trabes istae Hildesheimiae. Trabs igitur quam Iovianus Pontanus invenit in promontorio Pausyllipi, cum tempestas artem monte abrupuisset, qualis fuerit, non possumus scire; non enim explicatur an fuerit saxum, quod trabs speciem prae se ferebat, an lignum in saxum conversum»; Cesi owned copies of the treatise of Cesalpino and of Agricola (in the edition of 1616): cf. M. T. Biagetti, La biblioteca di Federico Cesi, Roma, Bulzoni, 2008, p. 266, $\mathrm{n}^{\circ} 151$ for Cesalpino, and pp. 271-272, n 2259 for Agricola. leaving open the possibility of arguing for a transformation from wood to stone, while leaving open two possible scenarios of the process: that of a slow transformation, projected into the past, and that of metamorphosis by lightning. But this ambivalence is common: we can find it for example in William Camden (1551-1623), ${ }^{30}$ and equally in Cesalpino, who seems reluctant to come down in favour of either opinion.

It is regrettable that Winther did not specify the nature of that 'certain point' with which Cesi had expressed his agreement. But we do know what his frame of reference was at the end of the year, thanks to the only extant fragment from the materials that the prince was compiling to deal with the matter in depth. This document owes its origin to the desire to address a letter to Cardinal Francesco Barberini with a concise explanation to accompany the gift of a table made of ebony. The brief but dense letter is intended above all to underline the importance of this discovery in the eyes of the cardinal because of its capacity to increase knowledge of the so-called intermediate nature, otherwise defined as entia imperfecta. Although Cesi stresses the completely unparalleled way in which these metallophytes combine two or even three natures, he locates their essential characteristic in their bituminous nature. This is followed by a list of examples of naturalia: the stones gagates (jet) and aetites (eagle stones), on whose disputed identification Cesi concurs with Pliny; ${ }^{31}$ another jet-like stone known as acciavaccio (the Neapolitan term for a dark stone known in Spanish as azabache and used as a talisman), fossil ebony, lithanthracite (these are simply named), and finally agalloch, aloe wood, whose

${ }^{30}$ Agricola De natura fossilium, p. 325: «Iidem autem fontes et fluvii chirotecas et ossa aliasque res in se immissas, ut forma prior maneat, ossaque dissolvens cum corpore tabificus seps, in lapidem conversus nuer ad rivum quendam montis piriferi salso dicti inventus est»; W. Camden, Britannia..., Londini, Impensis, Georg. Bishop, 1600, e.g. p. 542: «Ubi flumen australem agri limitem attingit inter ericeta et iacentia loca, in quibus, uti etiam alibi, arbores ab inundato mundo, ut credunt, defossas saepe eruunt»; p. 622: «Sub quo fons est in quem ex impendentibus rupibus aquae guttatim distillant, unde Dropping Well vocant, in quem quicquid ligni immittitur, lapideo cortice brevi obduci et lapidescere observatum est».

${ }^{31}$ Cited from Gabrieli, Il carteggio linceo, p. 966: «Fra questi ho veduti i nascimenti del Gagate, ancorché lontano dal Gange, del Aetite ad esso prossimo; nel che venga lodato Plinio, e liberato dalla calunnia, che communemente se l'è data, d'haverli insieme congionti»; the reference is Pliny X 12. Cesi read gagaten, the accepted reading in the editions until then, while modern editors (e.g. Detlefsen, Mayhoff, Rackham, De Saint Denis, König and Winkler) accept the reading gagiten; the principal ancient sources on the stone were Dioscorides V 129 and Pliny XXXVI 141. The latter is not free of errors, on which cfr. A. Mottana, "Ricerche di iconografia mineralogica: I. La pietra "gagate» nel Codex medicus graecus 1 della Biblioteca Nazionale Austriaca", Rendiconti della Accademia dei Lincei. Classe di scienze fisiche, matematiche e naturali, 2002, s. IX, 13: 89-112. 
legendary origin in terrestrial paradise Cesi mentions in passing. ${ }^{32}$ The list is intended to display the salient properties of the metallophyte, ${ }^{33}$ comprised within the spectrum of characters extending between the extremes of jet, which Pliny describes as 'black, smooth, porous, light, not very different from wood, and brittle, and has an unpleasant smell when rubbed ${ }^{34}$ and of agalloch, noted for its fragrance. ${ }^{35}$

According to Francesco Stelluti, the detailed description of the naturalia in this list and their relation with metallophytes would have corresponded to the treatise on which Cesi was working. ${ }^{36}$ Stelluti regretted that Cesi's early death had prevented him from completing it and saved the most valuable part - the woods of Acquasparta - from oblivion when he dedicated a brief Trattato to them in 1637. Stelluti presents his own thesis as the result of a laborious intellectual trajectory that involved the rejection of what he claimed as the most natural

\footnotetext{
${ }^{32}$ Presumably Cesi took the legend from P.A Mattioli, Commentarii secundo aucti in libros sex Pedacii Dioscoridis Anazarbei de materia medica..., Venetiis, In officina Valgrisiana, 1560, p. 48: «Sunt qui somniantes dixerint Agallochi arborem vidisse neminem, cum terrestri tantum paradiso proveniat, illudque ferri fabulantur fluminibus quae (ut sacra testantur monumenta) ex eo manant. Atqui pro comperto habetur (ut paucis innuit Serapio) Gangem Indiae amplissimum fluvium quam plurima secum Agallochi fragmina vehere, quae tamen in ipsum ducuntur aliorum fluminum cursu, qui in eum confluunt. Quippe cum fluvii transluant loca, ubi Agallochum provenit, aquarum inundationibus turgentes, huius truncos, fragmina ac ramenta rapiunt una cum aliis varii generis lignis, et in Gangem transferunt, quemadmodum in nostris etiam fluminibus saepe ac saepius visitur. Cuius rei indicium affert illud quod Venetiis venditur, utpote quod longo aquarum discursu omni ex parte laceratum, exesum, comminutumque spectetur»; the primary source for the agallochum is Dioscorides I 22.

${ }^{33} \mathrm{~A}$ very forced interpretation of this list is proposed by D. Freedberg, The Eye of the Lynx. Galileo, His Friends, and the Beginnings of Modern Natural History, Chicago and London, The University of Chicago Press, 2002 , pp. 327-328, though as a preliminary to an interpretation of Cesi's mineralogical researches on which serious doubts have been cast by $\mathrm{P}$. Galluzzi, «Libertà di filosofare in naturalibus». I mondi paralleli di Cesi e Galileo, Roma, Scienze e Lettere, Accademia Nazionale dei Lincei, 2014, pp. 425-426 [= Idem, The Lynx and the Telescope. The Parallel Worlds of Federico Cesi and Galileo, trans. P. Mason, Brill, Leiden, 2017, pp. 382383].

${ }^{34}$ Pliny, XXXVI, 142: «Niger est, planus, pumicosus, levis, non multum a ligno differens, fragilis, odore si teratur gravis».

${ }^{35}$ Confirmation that the list serves to define the spectrum of the qualities of the metallophyte can be found in Stelluti's statement that the sample can emit a distateful odour like that of gagate, or a more pleasing one closer to the extreme sweetness of the scent of aloe wood: F. Stelluti, Trattato del legno fossile minerale nuovamente scoperto..., In Roma Appresso Vitale Mascardi, 1637, p. 7: «Se si mette al fuoco mentrè stato cavato di fresco dalla terra, s'abbrucia, ma lentamente con gran fumo, e con odore spiacevole. Quando poi il legno è secco, l'odore è più grato $[\ldots] »$.

${ }^{36}$ Ivi, pp. 11-12: «[P]oiché non solo scriveva della generatione di dette pietre e legno, e delle pietre aquilini, che pure in detti luoghi se ne genera gran quantità, ma di tutte l'altre pietre note sin qui, e di altre ancora non più osservate, ne descritte da altri Autori».
}

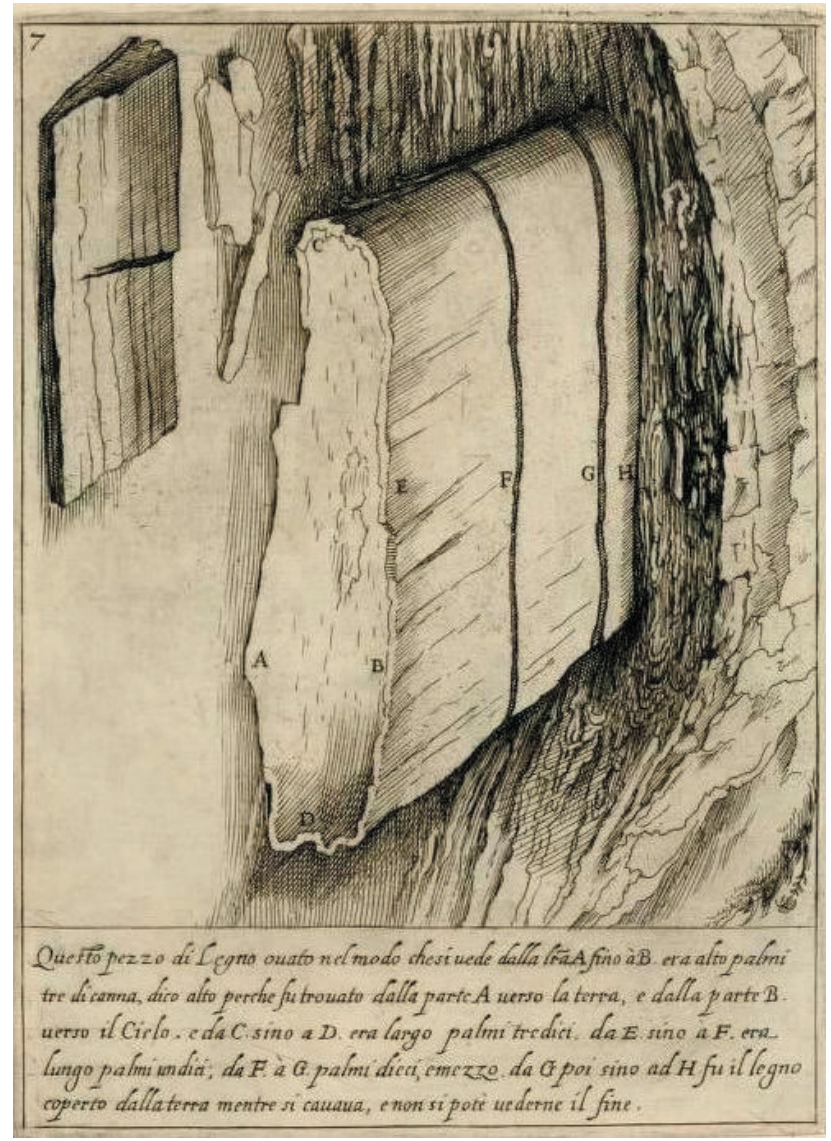

Figure 3. Plate from Stelluti, Trattato del legno fossile (1637). The annotation runs: "This piece of wood, ovoid from A to B, was three palms high; I say high because it was found with the part A facing downwards and the part B facing upwards; and from $\mathrm{C}$ to $\mathrm{D}$ it was thirteen palms long; from $\mathrm{E}$ to $\mathrm{F}$ it was eleven palms long; from $\mathrm{F}$ to $G$ ten and a half palms. From $G$ to $H$ the wood was covered with earth while it was being excavated, and it was impossible to see where it ended." Although the annotation does not mention it, the fragments represented on the upper left were presumably detached during the excavation.

hypothesis, viz. that they were the remains of trees buried a long time before that had slowly been transformed into stone. ${ }^{37}$ The absence of roots, seeds and other circumstantial evidence led him ineluctably to the idea that they originated from 'a soil type containing a lot of chalk, which gradually converts it into wood' (see Fig. 3).

${ }^{37}$ Ivi p. 6: «Ne meno si può credere, che questi legni siano tronchi o frusti d'alberi sotterrati in quei luoghi, o caduti, e dalla terra ricoperti, e formati poi con quellonde da quellacque minerali, che ivi scaturiscono, e da fuochi sotterranei, com'io nel principio mi persuasi, per haver trovato alcuni olmi ricoperti dalla terra in quei luoghi, dove detto legno si trova, perché la sua forma si varia, e la mole si grande mi fa credere il contrario, non trovandosi alberi mai dalla natura formati come nelle seguenti figure si vedrà [...]»; on Stelluti cf. Francesco Stelluti Linceo di Fabriano, Fabriano, Città e comune di Fabriano, 1986. 
It has been repeatedly claimed that such a thesis could not have appealed to Cesi because of its excessive naïveté, but apart from the fact that comparison of the letter to Barberini with the text of Stelluti does not afford any positive evidence for such a difference of opinion, there is a clue that enables us to qualify Stelluti's thesis as fully compatible with the philosophical horizon of Cesi enshrined in the Tabulae Phytosophicae. They show a clear adhesion to the Paracelsian doctrine of transplantatio. This doctrine allows that, given certain conditions, the process of changing along the axis of the natural continuum that usually proceeds downwards (commonly defined as degeneratio) can operate in the reverse direction and even perform considerable leaps. ${ }^{38}$

\section{FROM THOMAS BARTHOLIN TO JOHANN JAKOB SCHEUCHZER}

However eccentric and extreme the solution suggested by Cesi and Stelluti, it remains anchored to the vision of nature summed up in the action of rationes seminales or spiritus metallicus. ${ }^{39}$ This vision was by no means marginal in the course of the seventeenth century, and often adopted in order to explain the origin of fossils and figured stones, from Johann de Laet's De gemmis et lapidibus libri duo (1647), ${ }^{40}$ and Ulisse Aldrovandi's Musaeum metallicum, posthumously edited in $1648,{ }^{41}$ to the catalogue of Manfredo Settala's Wunderkammer. ${ }^{42}$ This helps to understand why the Trat-

\footnotetext{
${ }^{38}$ On this aspect cf. Ottaviani, "Methodus philologica e naturales quaestiones, op. cit.

${ }^{39}$ Obviously, this notion had a long history: see H. Hirai, Le concept de semence dans les théories de la matière à la Renaissance: de Marsile Ficin à Pierre Gassendi, Turnhout, Brepols, 2005, and A. Clericuzio, Elements, Principles and Corpuscles. A Study of Atomism and Chemistry in the Seventeenth Century, Dordrecht-Boston, Kluwer, 2000.

${ }^{40}$ See Johann de Laet, De gemmis et lapidibus libri duo..., Lugduni Batavaorum, Ex officina Ioannis Maire, 1647, p. 177: «Quemadmodum spiritus metallicus a Deo terrae natura inditus, in venis auri argentique mirabilia artificio efformat arbusculas et herbas, ex auro et argento, ita in lapidicinis etiam varias effigies testaceorum animantium e materia plane lapidea et quasi metallica, quod et supra vidimus in lapidibus serpentinis et cornua Ammonis. Quare meo iudicio frustra sunt qui opinantur has conchas aliquando testaceas fuisse et viva animantia continuisse et successi temporis in lapides esse conversas».

${ }^{41}$ Cf. U. Aldrovandi, Musaeum Metallicum in libros IIII distributum, Bononiae, Typis Io. Baptistae Ferronii 1648.

${ }^{42}$ Cf. Museum Septalianum Manfredi Septalae patritii Mediolanensis industrioso labore constructum, Pauli Mariae Terzagi physici... descriptum..., Dertonae, Typis Filiorum qd. Elisei Violae 1664; Museo o Galeria adunata dal sapere e dallo studio del Sig. Canonico Manfedo Settala nobile milanese, descritto in Latino dal Sig. Dott. Fis. Paolo Maria Terzago et hora in Italiano dal Sig. Pietro Francesco Scarabelli Dott. Fis. di Voghera e dal medesimo accresciuta, in Tortona, Per li Figliuoli del qd. Eliseo Viola 1666.
}

tato del legno fossile minerale was, with a few very rare exceptions, ${ }^{43}$ favorably received as, for example, by Fortunio Liceti (1577-1657), Martin Schoock (1614-1669), Charles Patin (1633-1693), and Athanasius Kircher (16021680). ${ }^{44}$ More interesting is the case of the Danish physician Thomas Bartholin (1616-1680), who in 1643 went on a long Italian tour that took him to Rome, Naples, Sicily and Malta. In the course of his journey, he wrote that, in the course of planning a treatise on this material, he had arrived at a view of the glossopetrae that in no way agreed with that of Colonna. ${ }^{45}$ At the same time as he rejected the conclusions of the latter's dissertation, Bartholin, who recorded having seen 'the spectacle of the new wood' in Rome, had no objection to the thesis of Stelluti. ${ }^{46}$ Bartholin thereby gave form to a duality that was destined to be repeated, although two decades later Colonna's thesis seems to be widely acknowledged, for example by Johann Daniel Major (1634-1693) and Her-

${ }^{43}$ G. Naudé, Lettres inédites écrites d'Italie à Peiresc, 1632-1636, publiées et annotés par Philippe Tamizet de Larroque, Paris, Léon Techener, 1887, pp. 42-43, 51-52.

${ }^{44} \mathrm{Cf}$. F. Liceti, De tertio-quaesitis per epistolas clarorum virorum, medicinalia potissimum, et aliarum disciplinarum arcana postulantium responsa..., Utini, Ex Typographia Nicolai Schiratti, 1646: Liceti resp. De multiplici generatione Succini, Eboris, Ebeni et ligni, deque viribus Electri, pp. 200-201; M. Schoock, Tractatus de turffis ceu cespitibus bituminosis..., Groningae, Typis Johannis Cöllenii, Bibliopolae et Typographi, 1658, pp. 72-74; C. Patin, Traité des tourbes combustibles..., A Paris, Chez Jean Du Bray, aux Espics-Meurs et Pierre Variquet. À l'Enseigne du Gril, 1663, p. 45; A. Kircher, Mundus subterraneus in XII libros digestus, Tomi 2, Amstelodami, Apud Joannem Janssonium et Elizeum Weyerstraten, 1664-5, especially II, p. 65 on Stelluti's treatise.

${ }^{45}$ T. Bartholin, Epistolarum medicinalium a doctis vel ad doctos scriptarum centuria I et II, Hafniae, Typis Matthiae Godiccheni, 1663: Centuria I. Epistola LIII. De raris naturae in Insula Melita observatis, pp. 223-224; Epistola LVI. De Glossopetris Melitensibus, p. 240: «Nam de Glossopetris optimum agnosco iudicium tuum, quae cur ex metallorum ordine exigendae sint, basin rationum parum firmam apud $\mathrm{F}$. Columanm observo, de quibus incoram pluribus, si Deo visum est, agemus»; Epistola LVII. De Glossopetris, pp. 241-242.

${ }^{46}$ T. Bartholin, De Unicornu observationes novae..., Patavii, Typis Cribellianis, 1645, pp. 283-284: «Novi Ligni spectaculo ex terrea lapidi mixta materie saeculum nostrum illustravit nuper Natura duobus retro messibus, Aquaspartae in Umbria, ubi lignum fossile inventum cedro Mauritanico simile, venis in longitudinem extensis, non in altitudinem, quia radice caret, cortice interdum fragili, aliquando durissima et aspera partim lignea partim cretacea, sed medulla duriore. Mirum variantis naturae miraculum cum stupore apud unicum eius inter mortales authorem Cassianum Puteum vidi, et in rei fidem dono singulari aliquam eiusdem ligni partem rudem partim, partim tornatam, servo. Resinam lignorum instar sudat candidam mastichi similem vel thuri, metallique filamenta quaedam habet et capillamenta, ut nomen metallophyti impetravit a Francisco Stelluti qui totam eius historiam Etrusco idiomate cum depicto ligno typis Romae vulgavit, ubi et terram fossilis huius materiam inde exploravit quod gleba ei adhaerens humida post aliquot menses tota evaserit lignea, a calore, ut arbitror, temperato, quem modica oleosque humiditas in sicciorem lapidem vetat indurescere». 
mann Conring (1606-1681), ${ }^{47}$ and, with more substantial evidence, by Steensen in his Canis Carchariae dissectum caput (1667) and Prodromus (1669), ${ }^{48}$ and Scilla, in his La vana speculazione disingannata dal senso, edited in $1670 .^{49}$

In 1671 Paolo Boccone (1633-1704), when he was in Paris, published a series of observations in two modest volumes. ${ }^{50}$ France was the first stage of the journey that he had reluctantly undertaken once it had become clear that he would be unable to remain in Tuscany, where he had found his niche as personal botanist to the Grand Duke. One of the two works was on the nature of fossils. Convinced like Colonna that they originated from plants and animals, ${ }^{51}$ Boccone crossed the Alps in the knowledge that his thesis was finding confirmation by Steensen with whom he was on cordial terms. As it happened, 1671 was the year in which Steensen's theses were severely criticised by Martin Lister (1639-1712). ${ }^{52}$ In a letter of 13 December 1673, Henry Oldenburg wrote to Lister:

I have now in my custody a boxe, left with me by a Sicilian, Paulo Boccone, (an inquisitive person, especially as to Plants and Figured stones,) for the repository of the R. Society; in which, amongst other curiosities, there are sev-

\footnotetext{
${ }^{47}$ See J.D. Major, Dissertatio epistolica de cancris et serpentibus petrefactis..., Jenae, Typis Joannis Nisii, Sumptu Esaiae Fellgiebeli, Bibliop. Vratislav. 1664, and H. Conring, De antiquissimo statu Helmestadii et viciniae coniecturae, Helmestadii, Typis et impensis Henningi Mulleri, 1665, pp. 35-36: «Sunt scilicet talia dentes carchariae, aut lamiae, aliorumque cetaceorum marinorum. Quod praeclare docuit singulari dissertationi Fabius Columna, de Melitensibus eiusmodi glossopetris disputans».

${ }^{48} \mathrm{~N}$. Steensen, Canis Carchariae dissectum caput et dissectus piscis ex canum genere, in Id., Elementorum myologiae specimen..., Florentiae, Ex typographia sub signo stellae, 1667; De solido intra solidum naturaliter contento dissertationis prodromus..., Florentiae, Ex typographia sub signo stellae, 1669.

${ }^{49}$ A. Scilla, La vana speculazione disingannata dal senso. Lettera responsiva circa i corpi marini che petrificati si trovano in varii luoghi terrestri, Napoli, Appresso Andrea Colicchia, 1670.

${ }^{50} \mathrm{P}$. Boccone, Recherches et observations naturelles and Recherches et observations curieuses sur la nature du corail blanc et rouge, vray de Dioscoride, both Paris, Chez Claude Barbin, 1671.

${ }^{51}$ On Boccone's research on fossils cf. B. Accordi, "Contributions to the History of Geological Sciences; Paolo Boccone (1633-1704) - A Practically Unknown Excellent Geo-paleontologist of the 17th Century", Geologica Romana 1975, 14: 353-359.

${ }^{52}$ M. Lister, "A Letter... written at York August 251671 confirming the Observation in $\mathrm{N}^{\circ} 74$ about Musk sented Insects; adding some notes upon D. Swammerdam's book of Insects, and on that of M. Steno concerning Petrify'd shells", Philosophical Transactions, 1671, 6: 2281-2285; on which cf. N. Morello, "Le «conchiglie stravaganti» da Colonna a Lister", in Il Meridione e le scienze (secoli XVI-XIX) (ed.: P. Nastasi) Palermo, Università di Palermo, Istituto Gramsci Siciliano di Palermo, Napoli, Istituto Italiano per gli Studi Filosofici, 1988, pp. 257-279; A.M. Roos, Web of Nature: Martin Lister (1639-1712), the First Arachnologist,
} Leiden-Boston, Brill, 2011. eral pieces of Coral, red and white, some hard and solid, others britle sticking about pieces of wood etc. which latter may much inform us about the original of coral, and teach us, that'tis of a stony, not vegetable nature..$^{53}$

Boccone had hardly left England, the second stage of his journey, where he had made a favourable impression. He now headed for Holland, where he was to publish the Parisian works in a single volume in Amsterdam in 1674, taking into account the recent English and Dutch discoveries. He made no mention of Lister; ${ }^{54}$ we do not know the reason for this silence, but it may be supposed that the Englishman's objections, which ended up reviving the 'plastic virtue' hypothesis, may have had a déjà$v u$ ring to Boccone. The abovementioned Scilla's treatise was ably promoted by Boccone; in that work Scilla replied point by point to the letter in which the Maltese physician Giovan Francesco Buonamici (1639-1680) opposed the Colonna/Steensen position, based on an elaborate version of the genesis of fossils and other figured stones by the action of occult seeds. ${ }^{55}$

The successive decades, however, had more than one surprise in store for Boccone. Both in England and on

${ }^{53}$ The Correspondence of Dr. Martin Lister (1639-1712). Volume One: 1662-1677, (ed.: Anna Marie Roos), Leiden-Boston, Brill, 2015, p. 639; Oldenburg is providing Lister with a synthesis of the content of the "Account of some of the Natural things, with which the Intelligent and Inquisitive Signor Paulo Boccone, of Sicily hath lately presented the Royal Society, and enriched their Repository" already published in Philosophical Transactions, 1673, 6158-6161.

${ }^{54} \mathrm{P}$. Boccone, Recherches et Observations naturelles..., Amsterdam, Chez Jean Jansson à Waesberge, 1674, where Lister is also passed over in silence, "A description of certain stones figured like plants, and by some observing men esteemed to be plants petrified..., Philosophical Transactions 1673, 8: 6181-6191, although he added considerable material on the astroite: ivi, cf. pp. 118-124, 135-149.

${ }^{55}$ Buonamici's letter was printed much later: cf. G.F. Buonamici, "Lettera missiva... diretta ad Agostino Scilla.... ove si tratta dell'origine delle glossopietre, occhi di serpi, bastoncini detti di san Paolo, ed altre pietre figurate, che si cavano dall'isola di Malta e del Gozzo", in Opuscoli di Autori Siciliani, Palermo, Per Pietro Bentivenga, 1770, vol. XI: 105-195, 188: «Né anco è da credere a mio parere, che solamente i semi occulti, e principi materiali di quell'animaletti minuti e stimati comunemente meno perfetti si contengono dispersi nell'acqua e nella terra, ma anco de' maggiori e più perfetti, sicché questi potrebbono similmente generarvisi, toltone però l'uomo, la di cui produzione non fu commessa alla terra, ma riserbata alla mano dell'Altissimo, come della più perfetta delle creature, chè composta di spirito e corpo, checché si sia sognata la pagana antichità e de' suoi Preadamiti abbia empiamente scherzato la Perriera moderno scrittore, de' suoi omicciuoli fatti per arte chimica entro una caraffa scrisse Paracelso, e di non so che razza d'uomini verdi scappati dal seno della terra lasciò registrato il Neobrigense»; Buonamici had already stated his position in a letter to Michele Giustiniani, published by the latter in Lettere memorabili... parte prima, Roma, Per Nicolò Angelo Tinassi, 1667, pp. 389-404; on him cf. N. Morello, "Giovanni Francesco Buonamico and the Fossils: A Flood of Problems", in Italian Scientists in the Low Countries in the XVIIth and XVIIIth Centuries, (ed. Cesare S .Maffioli - Lodewijk C. Palm), Amsterdam-Atlanta, GA, Rodopi, 1989, pp. 131-145. 
the continent, the challenge of Lister and Buonamici was taken up in a sequel of interventions, which, irrespective of the arguments deployed to reject totally or to limit the validity of the theses of Colonna and Steensen, had in common a view holding that fossils originate by plastic virtue or occult seeds. ${ }^{56}$ Quite eloquent was the case of the Swiss physician Johann Jakob Scheuchzer. Born at Zürich in 1672, graduated at the University of Utrecht, Schuechzer in 1697 published an essay entitled De generatione conchitarum. ${ }^{57}$ Still far from wholeheartedly embracing the diluvian theory that he was soon to adopt after reading the works of John Woodward ${ }^{58}$ Scheuchzer treated this complex material warily, cautiously weighing up the two major theses in open conflict, and eventually (with many reservations) came down on the side of Steensen, whose works he read with great care. $.^{59} \mathrm{Nev}-$ ertheless, only a few years later Scheuchzer continued to appreciate that position but restricted its scope even further as he grew inclined to accept the arguments of those who clung firmly to panspermia, the spiritus mun-

56 That is the case of John Ray, Robert Plot Edward Lhwyd, Johann Jakob Wagner, Johann Jakob Reiskius, Theodor Geyer, Elias Camerarius, Karl Nikolaus Lange, just to cite a few.

${ }^{57}$ J.J. Scheuchzer, "De generatione conchitarum", Miscellanea curiosa sive Ephemeridum medico-physicarum Germanicarum Caesareo-Leopoldinae naturae curiosorum 1697, 4, Appendix: 151-166, pp. 155 and 157: «Non etiam immorabor multum [...] descriptioni accuratiori figurae conchitarum [...] ut nec solutioni famosae illius apud litographos quaestionis, num sc. conchitae aliique lapides figurati fuerunt aliquando revera conchae, cochleae \&c. fluviatiles vel marinae, atque adeo spolia diluvii universalis, inundationum particularium, absorbitionum terrae, quae postea in terra relicta a petrificante quodam succi il lapides transmutata vi, an non potius sint id genus lapides corpora terrigna, atque adeo mire variantes suas figuras terrae debeant, non mari; corporibus inanimatis, non incolis maris, animalibus variis. [...]»; e p. 157: «Non satisfacit mihi,

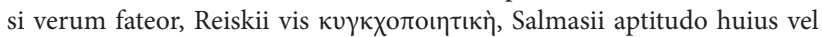
illius loci peculiaris, ad continendum eiusmodi succum conchiferum, Geyeri succus lapidescens, et sal illud modificans Wagneri et aliorum vis seminalis terrae innata»; on him cf. M. Kempe, Wissenschaft, Theologie, Aufklärung. Johann Jakob Scheuchzer (1672-1733) und die Sintfluttheorie, Epfendorf, Bibliotheca Academica Verlag, 2003.

${ }^{58}$ The hesitations, still present in Specimen lithographiae Helveticae curiosae, Tiguri, Typis Davidis Gessneri, 1702, disappear from Piscium Querelae et Vindiciae, Tiguri, Sumtibus Authoris, Typis Gessnerianis 1708.

${ }^{59}$ Cf. Scheuchzer, "De generatione conchitarum", pp. 155 and 157: «Non etiam immorabor multum [...] descriptioni accuratiori figurae conchitarum [...] ut nec solutioni famosae illius apud litographos quaestionis, num sc. conchitae aliique lapides figurati fuerunt aliquando revera conchae, cochleae \&c. fluviatiles vel marinae, atque adeo spolia diluvii universalis, inundationum particularium, absorbitionum terrae, quae postea in terra relicta a petrificante quodam succi il lapides transmutata vi, an non potius sint id genus lapides corpora terrigna, atque adeo mire variantes suas figuras terrae debeant, non mari; corporibus inanimatis, non incolis maris, animalibus variis. [...]»; e p. 157: «Non satisfacit mihi,

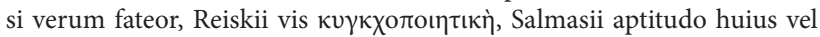
illius loci peculiaris, ad continendum eiusmodi succum conchiferum, Geyeri succus lapidescens, et sal illud modificans Wagneri et aliorum vis seminalis terrae innata». di or the archeus espoused by van Helmont. ${ }^{60}$ We do not know whether his change of attitude was also influenced by his turning attention to vegetal forms, but it is certain that, whether willingly or not, in the divergence resulting from the juxtaposition of the two sententiae, Scheuchzer ended up reproducing a polarity whose dialectical tension had been taken to its limit by the Accademia dei Lincei.
${ }^{60}$ Cf. J.J. Scheuchzer, "Dissertatio epistolica Acarnanis de Dendritis aliisque lapidibus, qui in superficie sua plantarum, foliorum, florum figuras exprimunt", Miscellanea curiosa sive Ephemeridum medico-physicarum Germanicarum Caesareo-Leopoldinae naturae curiosorum, 1700, 5-6, Appendix: 57-80, p. 67: «Sic non improbaverim eorum sententiam, qui Spiritui mundi, Archeo sive natura universali, in globum hunc terraqueum ubique panspermia imbutum perpetuo agenti, et pro subiecti diversitate figuras varias producenti cuncta tribuunt»; on van Helmont see W. Pagel, Joan Baptista van Helmont: reformer of science and medicine, Cambridhe [et alibi], Cambridge University Press, 1982. 